\title{
A spatial assessment model for European eel (Anguilla anguilla) in a delta, The Netherlands
}

\author{
K.E. Van De Wolfshaar ${ }^{(1), \star}$, N. Tien ${ }^{(1)}$, H.V. Winter ${ }^{(1)}$, M. De Graaf ${ }^{(1)}$, \\ S.M. Bierman ${ }^{(1), \star \star}$
}

Received June 10, 2013

Revised October 4, 2013

Accepted October 15, 2013

\begin{abstract}
Key-words: model, GIS, Water Framework Directive, stock assessment

Given the poor status of the European eel (Anguilla anguilla) population, good assessments are essential to optimise recovery measures. Quantifying eel stock size is challenging given the fractal nature of the distribution of eels, particularly in The Netherlands with its dense interconnected network of drainage ditches, rivers and lakes. Dynamic demographic models as used by others are inappropriate in this delta with a demand for regional information on stock size. We therefore estimated the standing eel stock biomass for all freshwater water bodies, using fish monitoring data collected under the Water Framework Directive and a static GIS approach. Density data were extrapolated to total biomass estimates using GIS data concerning water type, surface area and bank length, and biological parameters obtained from biological data. The analysis yielded density and biomass estimates of the total eel and silver eel stock, with most silver eel biomass being confined to a few coastal regions. The main conclusion is that over half of the Dutch eel biomass is found in the small, regionally managed waters, revealing a crude underestimation of the eel biomass in the 2009 Dutch Eel Management Plan. The silver eel biomass estimate presented here is two to three times higher than previous estimates. Providing spatial information on eel biomass will aid in prioritising management measures to reduce anthropogenic mortality.
\end{abstract}

\section{ABSTRACT}

RÉSUMÉ

Un modèle d'évaluation spatiale de l'anguille européenne (Anguilla anguilla) dans un delta aux Pays-Bas

Mots-clés : modèle,

SIG, directive cadre sur l'eau,
Compte tenu de la mauvaise situation de la population de l'anguille européenne (Anguilla anguilla), de bonnes évaluations sont essentielles pour optimiser les mesures de restauration. Quantifier la taille du stock d'anguilles est difficile compte tenu de la nature fractale de la distribution de l'anguille, en particulier aux PaysBas avec son dense réseau interconnecté de fossés de drainage, de rivières et de lacs. Les modèles de dynamiques démographiques utilisés par d'autres ne sont pas appropriés dans ce delta à une demande d'information régionale sur la taille du stock. Nous avons donc estimé la biomasse du stock d'anguille pour tous les plans d'eau douce, en utilisant les données de surveillance des

(1) Institute for Marine Resource and Ecosystem Studies (IMARES), Wageningen UR, PO Box 68, Haringkade 1, IJmuiden, The Netherlands

* Corresponding author: karen.vandewolfshaar@wur.nl

** Current address: Statistics \& Chemometrics, Shell Global Solutions International BV, P.O. Box 38000, 1030 BN Amsterdam, The Netherlands 
évaluation de stock

\begin{abstract}
poissons recueillies en vertu de la directive cadre sur l'eau et une approche SIG statique. Les données de densité ont été extrapolées pour estimer la biomasse totale en utilisant des données SIG concernant le type de masse d'eau, la surface et la longueur de la berge, et les paramètres biologiques obtenus à partir de données biologiques. L'analyse a abouti à des estimations de la densité et de la biomasse totale du stock d'anguilles argentées, avec la majorité de la biomasse d'anguilles argentées confinée à quelques régions côtières. La principale conclusion est que plus de la moitié de la biomasse d'anguilles néerlandaises se trouve dans les petites masses d'eau, gérées à l'échelle régionale, conduisant à une sous-estimation importante de la biomasse d'anguilles dans le plan néerlandais 2009 de gestion de l'anguille. L'estimation de la biomasse d'anguilles argentées présenté ici est de deux à trois fois plus élevée que les estimations précédentes. Fournir de l'information spatiale sur la biomasse d'anguilles aidera à choisir les priorités dans les mesures de gestion pour réduire la mortalité anthropique.
\end{abstract}

\section{INTRODUCTION}

Given the strong decline of European eel (Anguilla anguilla), there is a need for adequate measures in an attempt to halt this negative trend (WGEEL 2012, ICES 2012). Shortly after the introduction of the EU Regulation for the Recovery of the Eel Stock (EC 1100/2007), member states were required to develop eel management plans (Ministry of Agriculture, 2009). The first progress reports were submitted to the European Commission in 2013 and the evaluation of the progress of the eel management plans will take place, yet most ICES advice was based on recruitment time series. Unlike marine fish stocks where member states collate fisheries data to be used in a single stock assessment, during the last 5 years almost all countries have developed their own national assessment model for eel (e.g. Aprahamian et al., 2007; Bevacqua et al., 2007; Ciccotti et al., 2012; Oeberst and Fladung, 2012).

The models developed for eel stock assessments are mostly dynamic demographic models of an eel population in a single catchment using age, stage or cohorts (Dekker, 2000; Oeberst and Fladung, 2012). This type of model is highly appropriate in a setting with a relatively simple, natural, catchment (e.g. Ciccotti et al., 2012) or a rough broad-scale approach (Dekker, 2000) and for The Netherlands this approach has been applied to the largest lake, Lake ljsselmeer, treating it as a closed system only connected to the sea (Ministry of Agriculture, 2009). This approach is insufficient, however, for a national assessment. The Netherlands consists of a highly complex delta with many small catchments, and including many manmade, often interconnected, water bodies (Figure 1) and there is a demand for small-scale knowledge on the eel stock. In addition, most water bodies are managed at a regional level and only the large rivers and lakes at a national level, resulting in mostly regional-level decisions on water management. This makes the use of a dynamic modelling approach difficult, and also as many often small entrances and exits for glass eel and silver eel exist which are not all monitored. To tackle this issue a static GIS approach was adopted to assess the eel stock in the Netherlands, based on Water Framework Directive (WFD) fish sampling, which can satisfy the demand for regional-level information on the eel stock.

The regionally managed freshwater water bodies make up $65 \%$ of the total water freshwater surface area (PBL, 2010) but these waters were not surveyed in a regular and standardised way before the implementation of the European Water Framework Directive in 2000 (2000/60/EC) (WFD).

Standardised fish surveys have been conducted in the nationally managed water bodies (Figure 1) since 1966 (Lake IJsselmeer and Markermeer) and since 1990 in the main rivers (Rhine, Waal, Meuse and IJssel). To determine the biomass of escaping silver eel in the Dutch Eel Management Plan in 2009, only these nationally managed waters were taken into account (Ministry of Agriculture, 2009). Due to the lack of information on eel in the rest of the water bodies these could not be taken into account. 

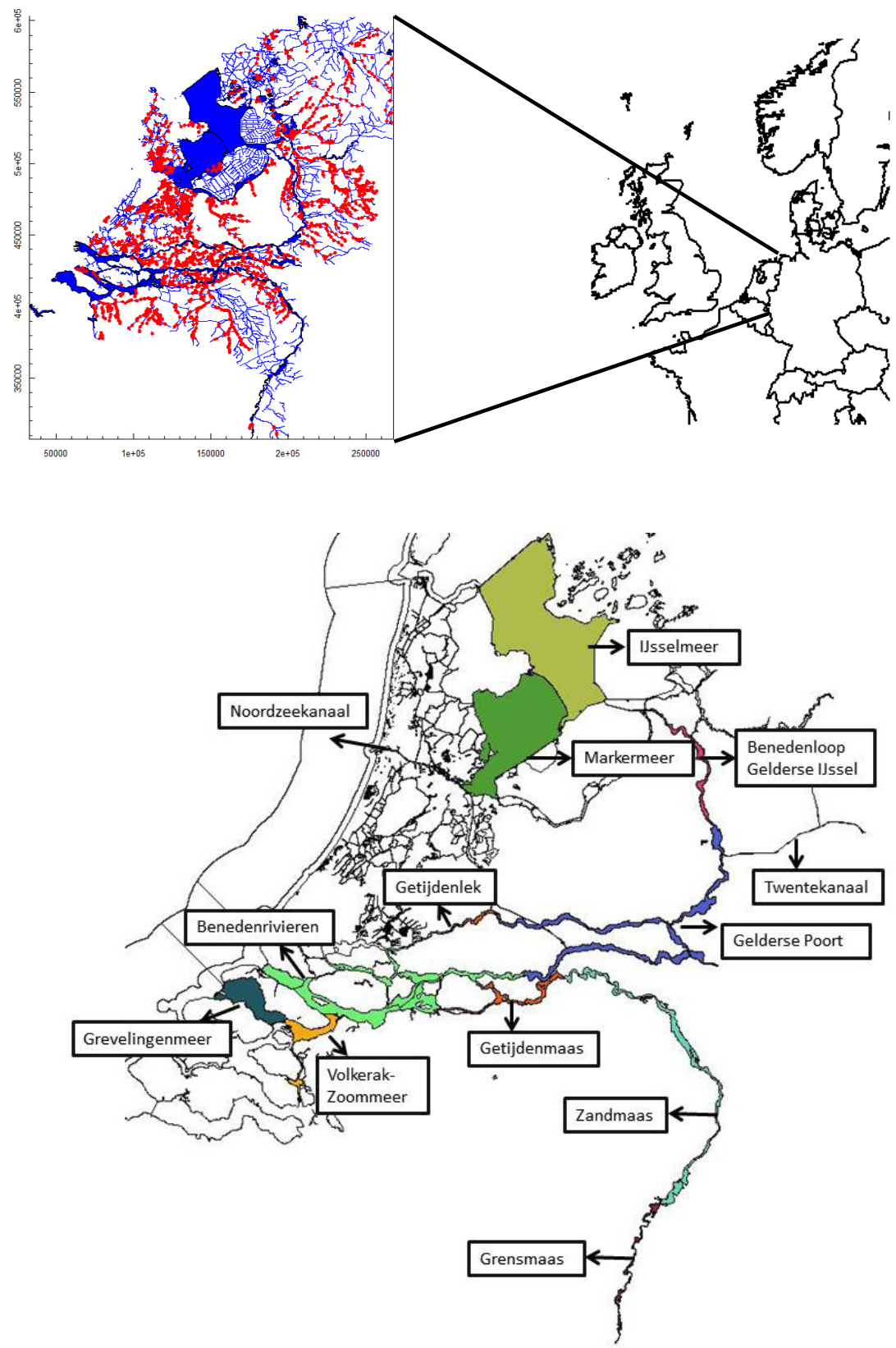

\section{Figure 1}

Map of Western Europe and the Netherlands with all its water bodies. Locations of WFD electrofishing samples used in the model are given in red dots. The bottom map shows the national waters and the geographical names of lakes and river sections.

The WFD requires assessment methods for different water body types and different groups of organisms, with a focus on ecosystem integrity. The fish measures are generally considered in relation to the ecological status of the water body (Noble et al., 2007). In addition to the existing fish surveys in the nationally managed waters, in 2006 the regionally managed waters were implemented in the WFD programme. From then on, both the nationally and regionally managed water fish surveys fall under the WFD programme. The strength of the WFD fish sampling is that it uses standardised fish sampling protocols and hence provides a nationwide valuable data set with spatially explicit information on eel densities.

Here we present a spatial assessment model for European eel in regionally and nationally managed inland water bodies in The Netherlands, based on WFD sampling. With spatially 


\section{Table I}

Water body types defined within the Water Framework Directive in The Netherlands that were taken into account in this study of regionally managed waters. For those water types accounted for by the line map the average width used in the model to calculate the surface area is presented (STOWA, 2007a, 2007b). For those water bodies of a certain water type that are on the polygon map the surface area from the map is used and hence no average width is needed. ' $R$ ' types are natural and flowing, while ' $M$ ' types are non-natural lakes, channels or ditches (STOWA, 2007a, 2007b). Surface area (not corrected for in-offshore) and total number of electrofishing surveys (n) per type are given.

\begin{tabular}{|l|l|c|c|c|}
\hline $\begin{array}{l}\text { Code water } \\
\text { type }\end{array}$ & Description & $\begin{array}{c}\text { Avg. } \\
\text { width (m) }\end{array}$ & $\begin{array}{c}\text { Surface } \\
\text { area (ha) }\end{array}$ & $n$ \\
\hline M1a/b & Buffered ditches & 4 & $156 / 0.06$ & $77 / 0$ \\
M2 & Weakly buffered ditches & 4 & 10 & 11 \\
M3 & Buffered regional canals & 11.5 & 3323 & 323 \\
M6a/b & Large, shallow canals with/without shipping & 15 & $603 / 1780$ & $55 / 152$ \\
M7a/b & Large deep canals with/without shipping & 15 & $13 / 3435$ & $0 / 93$ \\
M8 & Buffered fen ditches & 4 & 1148 & 42 \\
M10 & Fen canals & 1.5 & 1362 & 221 \\
M14 & Shallow, relatively large, buffered lakes & - & 37240 & 252 \\
M20 & Relatively large, deep, buffered lakes & - & 4444 & 49 \\
M23 & Shallow, large, calcium-rich lakes & - & 90 & 6 \\
M27 & Relatively large, shallow, fen lakes & - & 22738 & 207 \\
M30 & Weakly brackish waters & - & 2361 & 0 \\
R4 & Permanent, slow-flowing, upper reach, sand & 1.5 & 73 & 89 \\
R5 & Permanent, slow-flowing, middle & 6.5 & 1221 & 473 \\
& and lower reach, sand & 16.5 & 3414 & 199 \\
R6 & Slow-flowing small river, sand-clay & 15 & 2272 & 28 \\
R7 & Slow-flowing river, side channel, sand or clay & 6.5 & 65 & 11 \\
R12 & Slow-flowing middle and lower reach, bog & 1.5 & 4 & 0 \\
R13 & Fast-flowing upper reach, sand & 6.5 & 16 & 3 \\
R14 & Fast-flowing middle and lower reach, sand & 16.5 & 37 & 0 \\
R15 & Fast-flowing small river, pebble & 1.5 & 7 & 0 \\
R17 & Fast-flowing upper reach, calcium-rich & 6.5 & 52 & 25 \\
R18 & Fast-flowing middle and lower reach, calcium-rich & & & \\
\end{tabular}

explicit information on eel densities, future management actions on reduction of silver eel mortality can be directed towards areas with the highest impact.

\section{METHODS}

To estimate the eel stock in The Netherlands three data sources were used. For regionally managed waters the monitoring data and the water body typology provided by the WFD sampling programme were used. For the nationally managed waters the nationally managed WFD fish monitoring was used for the largest rivers, while reported landings and estimated fishing mortalities were used for the largest lakes (Lake IJsselmeer, Lake Markermeer, Lake Grevelingenmeer and Lake Veluwerandmeren). All the regionally managed water body types and nationally managed waters are provided in Tables I and II.

\section{> WFD WATER BODY DATA}

The total of 3402 water bodies that are defined within the WFD form the main basis for the stock assessment. These water bodies vary greatly in size, from small sections of streams or canals with surface areas smaller than $0.01 \mathrm{~km}^{2}$, to large water bodies such as lakes or sections of the main rivers with more than $100 \mathrm{~km}^{2}$ of surface area. Two different maps were available that contained these water bodies; a polygon map covering larger rivers and lakes, and a line map covering streams, channels and rivers (http://www.krwportaal.nl). These 


\section{Table II}

Surface area, river length (main river and connected side channels when present), bank length per river region or canal, and the number of electrofishing surveys ( $n$ ) of the nationally managed water bodies (if present).

\begin{tabular}{|l|c|c|c|c|c|}
\hline \multirow{2}{*}{ River or Lake } & \multicolumn{2}{|c|}{ Surface area (ha) } & \multicolumn{2}{c|}{ River bank length (km) } & \multirow{2}{*}{$n$} \\
\cline { 2 - 5 } & Main & Side channels & Main & Side channels & \\
\hline Beneden loop Gelderse ljssel & 675 & 270 & 118 & 42 & 19 \\
Beneden Rivieren & 18377 & 1670 & 702 & 498 & 95 \\
Gelderse Poort* & 5201 & 1468 & 857 & 191 & 140 \\
Getijdenlek & 500 & 78 & 52 & 19 & 30 \\
Getijden Maas* & 1265 & 753 & 224 & 82 & 36 \\
Grensmaas & 426 & 436 & 135 & 49 & 36 \\
Zandmaas & 2043 & 1413 & 305 & 160 & 57 \\
Twentekanaal & 396 & & 135 & & 2 \\
Lake Volkerak-Zoommeer & 4814 & & & & 9 \\
Noordzeekanaal & 2160 & & 235 & & \\
Lake Grevelingenmeer & 13902 & & & & \\
Lake IJsselmeer & 113743 & & & & \\
Lake Markermeer & 70064 & & & & \\
Lake Veluwerandmeren & 14790 & & & & \\
\hline
\end{tabular}

* For river sections Gelderse Poort and Getijden Maas groynes are present in the main river and the bank length given equals main river length plus groyne length (1.9 times river length).

were merged into a single database of unique water bodies by eliminating water bodies from the line map which were present in the polygon map. The water bodies were divided into regionally managed water bodies indicated by type (Table I) and nationally managed water bodies indicated by name (Table II) (see also Figure 1).

For each water body the surface area was used to scale the eel electrofishing samples (presented in numbers/ha) to density ( $\mathrm{kg} / \mathrm{ha}$ ) and to total surface area eel biomass (metric tonnes). When available, the surface area indicated by the polygon map was used. For those water bodies only present on the line map the average width per water body type obtained from the descriptors as provided for the WFD was used to estimate surface area (STOWA, 2007a, 2007b) (Table I).

The line map only contains $0.5 \%$ of the total of ditches present in The Netherlands, thereby neglecting 33000 hectares of ditches, assuming an average width of $1 \mathrm{~m}$ and $330 \mathrm{~km}$ ditch length (PBL, 2010). An estimate of the average eel density present in ditches was therefore based on the density estimates for the $0.5 \%$ present in the WFD fish survey sampling (M1a and M2) and scaled up to 33000 ha. For channels 10\% and for streams $30 \%$ were not represented within the WFD. These two non-represented surface areas together consist of 218 ha, i.e. $0.06 \%$ of the Dutch total water surface area, and were therefore considered negligible.

For the nationally managed large rivers, extra information on bank length was collected; in some parts of the rivers, bank length is significantly larger than river length because of groynes placed perpendicular to the riverbank. The groynes are made of boulders and provide suitable eel habitats. These groynes are approximately $90 \mathrm{~m}$ long and placed $200 \mathrm{~m}$ apart (www.rws.nl). In the parts of the rivers with groynes, bank length is thus approximately 1.9 times the river length. By visually scanning satellite images of Google Earth, a rough estimate of the percentage of riverbanks with groynes was made: $60 \%$ of the Gelderse Poort was estimated to have groynes, and $50 \%$ of the Getijdenmaas. In the other river sections hardly any groynes are present and were therefore not taken into account (Table II). In addition, surface area and length were obtained for the main riverbed and connected side channels separately, allowing for separate density estimates. 


\section{WFD Fish Survey data}

Fish sampling within the regionally managed WFD waters was done following an EU certified protocol (STOWA, 2003) using electrofishing. Sampled water bodies are representative of water types defined within The Netherlands based on WFD regulation. Sites within a water body were chosen randomly.

Sampling events, which included the latitude and longitude of the sample site, were checked as being in a WFD water body and only those located within WFD water bodies were taken into account. Firstly, coordinates which fell into a polygon were assigned to that polygon. Secondly, for the sampling events which could not be assigned to a polygon, the distance to line segments was computed, and the sampling event was assigned to the nearest line segment, based on longitude and latitude, as long as this was within $25 \mathrm{~m}$ of the sampling occasion. Thirdly, for all remaining sampling events without a match based on coordinates the water body names given at the time of the data collection were used to match these to the water body names in the GIS maps. This resulted in a total of 2325 electrofishing events covering the period 2006-2011 that were used for the eel assessment in regionally managed waters (Figure 1).

For the nationally managed rivers the sampling of a governmental survey programme was used for the stock assessment. In these surveys a beam trawl is used in the deeper parts and electrofishing near the river banks, and both the main river and the connected side channels are sampled. Only the data from the electrofishing were used because the catch efficiency of the beam trawl is unknown. Sampling occurs in autumn and early spring, with different sampling sites between seasons (Van Kessel et al., 2010). The rivers were divided into river sections, depending on the spatial distribution of the survey locations. Per river section, average eel density was determined, using data from 2008 to 2010 . For the nationally managed large lakes Lake IJsselmeer, Lake Markermeer, Lake Grevelingenmeer and Lake Veluwerandmeren the estimates were based on the reported landings (Bierman et al. 2012).

\section{> HORIZONTAL DISTRIBUTION OF EEL IN WIDE RIVERS AND LAKES}

Eels might prefer the shore over the open water (pers. obs. H.V. Winter and communication with fishermen), and almost all sampling took place near the shores of lakes or banks of rivers, streams or canals. The electric dipping net data was therefore taken as representative for eel densities near the shores or banks, whereas eel densities further from shores or banks were assumed to be lower (Jellyman and Chisnall, 1999; Schulze et al., 2004; Stevens et al., 2009b). However, no quantification of this is available and therefore the offshore density was estimated to be $50 \%$ of the inshore density. The width of the inshore zone is estimated as $1.5 \mathrm{~m}$ (Bierman et al., 2012). The inshore and offshore surface areas of each water body were calculated or obtained from the polygon map. For Grensmaas no correction for habitat preference between inshore and offshore was made, because this river section is very shallow, and also in the open water sampling takes place with the dipping net. Therefore, density in the open water was assumed to be equal to that in the littoral zone.

\section{Biological parameters}

The sampling data were presented as number of individuals and their length, measured in centimetres. The following length-weight conversion function was used to obtain the total weight per haul and per size class (De Graaf et al., 2011; Van Keeken et al., 2011).

$$
\text { Weight }=\exp \left(-14.45+3.217 \times \log _{\mathrm{e}}\right. \text { (length)) }
$$

Standing stock biomass estimates were generated for total eel and silver eel separately. Because no data on the eel maturity was collected, the fraction of silver eels was calculated using the key given in Table III. Per length class, individuals were divided into males and females. Subsequently, per gender the fraction of silver eels was estimated (Van Keeken et al., 2010). 


\section{Table III}

Sex ratio and maturity fractions per sex and length class (Van Keeken et al., 2010).

\begin{tabular}{|l|c|c|c|}
\hline Length class $(\mathrm{cm})$ & Male fraction & Silver eel fraction males & Silver eel fraction females \\
\hline $\mathbf{3 0 - 4 0}$ & 0.3182 & 0.1297 & 0.0106 \\
$\mathbf{4 0 - 5 0}$ & 0.0636 & 0.4489 & 0.0313 \\
$\mathbf{5 0 - 6 0}$ & 0 & & 0.0902 \\
$\mathbf{6 0 - 7 0}$ & 0 & & 0.2172 \\
$\mathbf{7 0 - 8 0}$ & 0 & & 0.4614 \\
$>\mathbf{8 0}$ & 0 & & 0.7747 \\
\hline
\end{tabular}

\section{Standing stock estimation}

\section{(a) Water bodies excluding the large lakes}

Mean production for the regionally managed waters was calculated by dividing the summed biomass by the summed swept area on a per water type and per water manager level. For the nationally managed rivers the production was calculated by dividing the summed biomass by the summed swept area per river section and for main rivers and the (permanently connected) side channels separately.

These estimates were then corrected for catch efficiency in order to achieve the total biomass estimates, assuming a catch efficiency of $20 \%$ (STOWA, 2003). Multiplying the production by the surface area of the water bodies, taking into account the distribution of eel inshore and offshore, as described above, and correcting for catch efficiency, resulted in the biomass per regionally managed water type or nationally managed water section.

Using the key in Table III (as described above), these density and biomass estimates were made for both total eel and silver eel.

For the regionally managed waters 20 of the 26 water types were present in the sampling data. Sampling data from 24 regional management areas out of the 30 areas present in the WFD programme were available. For those regional water types and management areas for which data were missing, the average density of the other regional water types and areas was used to estimate eel biomass. To make an estimate of the eel stock in the ditches the density estimate of those ditches that were present within the WFD (types M1a and M2) was used to upscale to the total ditch surface area. Direct estimates of silver eel biomass were based on a low sampling intensity (and thus uncertain length frequencies); we therefore used the average of silver eel out of the total eel biomass of the regionally managed water of $15 \%$ to estimate silver eel in the ditches.

\section{(b) The large lakes}

For Lake IJsselmeer and Lake Markermeer reported landings and survey data were available. For Lake Grevelingen and Lake Veluwerrandmeren only landings were available. The survey data were used to estimate fishing mortality in Lake IJsselmeer and Lake Markermeer. To do so, a population model was fitted to a time series of length structured indices from the surveys from Lake IJsselmeer and Lake Markermeer (Bierman et al., 2012). The fitted fishing mortality estimate of 0.2 year $^{-1}$ was then used to calculate the stock from the reported landings. No data were available for the other lakes to estimate fishing mortality and therefore the same value of 0.2 was used.

Density estimates were based on the stock estimate divided by the surface area of the lake. The reported landings were split into yellow eel and silver eel biomass using the lengthdependent sex ratio and silver eel fraction for males and females (Table III). The silver eel stock in these lakes was assumed to be $15 \%$ of the estimated yellow eel stock based on the average percentage in the regionally managed waters (Bierman et al., 2012).

All analyses were done with $\mathrm{R}$ (R Development Core Team, 2005). 


\section{RESULTS}

The total estimate of eel biomass in The Netherlands, based on sampling data from 2006-2011, is 3957 tonnes, of which $61 \%$ are present in the regionally managed water bodies (Table IV). A similar percentage holds for the silver eel stock, with $60 \%$ in the regionally managed waters. Overall, we estimate that $15 \%$ of the total eel biomass in the period 2006-2011 consisted of silver eel.

The average density and biomass estimates of eel differ greatly among the water types used for the regionally managed waters (Table IV). In general, the pattern is not unexpected, with high density estimates for the eutrophic, large lakes, both shallow and deep (M14 and M20). Especially M14 provides a major contribution (24\%) to the total eel biomass estimate, because of its high density as well as the large surface area (Table I). R7, the slow-flowing rivers or side channels with sand or clay, has the highest density estimate $\left(39.3 \mathrm{~kg} \cdot \mathrm{ha}^{-1}\right)$ and contributes almost $6 \%$ to the total biomass. M27, the large shallow lakes with valley bog, does not have a high density estimate but given the surface area has a high contribution to the total biomass estimate (10\%). The ditches, that are hardly represented in the WFD and therefore added to the national assessment, contribute over $8 \%$ of the total eel biomass.

With regard to the nationally managed water bodies, Lake IJsselmeer and Lake Markermeer have the highest total eel biomass estimate, while Lake Volkerak-Zoommeer has the highest density estimate (Table IV). For the river sections, density estimates differ between the main river and the connected side channels. Whether the side channels or the main river have the highest densities differs among sections. When comparing across river sections, the river section Grensmaas has the highest density in both the main river and the side channels, of 35 and $21 \mathrm{~kg} \cdot \mathrm{ha}^{-1}$, respectively. The river section Beneden Rivieren has the highest biomass estimate, which is due to its large area (Table II).

The silver eel density and biomass estimates follow the same pattern as the total eel density and biomass estimates for regionally and nationally managed waters (Table IV). Of the regionally managed waters, types $\mathrm{M} 14, \mathrm{M} 27, \mathrm{R} 7$ and the ditches contained the most silver eel biomass, while Lake IJsselmeer, Lake Markermeer and Lake Volkerak-Zoommeer and the river section Beneden Rivieren contained the most silver eel biomass of the nationally managed waters.

To identify the regional distribution of silver eel biomass relative to total silver eel biomass, the percentage of silver eel biomass per management area of the total Dutch silver eel biomass was plotted (excluding the ditches). These percentages of local silver eel to national silver eel are not evenly distributed throughout the country, nor along the coastline (Figure 2). The coastal area in the south-west (12\%) and a coastal area in the north (13\%) contain most of the total silver eel biomass, together $25 \%$. Areas in between and along the coast together contain only up to $8 \%$ of the silver eel biomass present. However, in general the highest silver eel biomass is present closer to the coast. This figure highlights that the silver eel concentrates in only a few areas, while most of the areas taken into account have less than $4 \%$ of the silver eel biomass each. These areas with little silver eel are mostly in the south-eastern part of the country. The highest percentage of silver eel biomass is in regionally managed waters and not in nationally managed waters such as Lake IJsselmeer (10\%) and Lake Markermeer (7\%). The same spatial pattern holds for the biomass of the total eel stock (not shown).

To identify the relative silver eel contribution of different regional areas to the total eel biomass, the percentage of silver eel per area of the total eel biomass for that same area was plotted (excluding the ditches). This percentage can be used as an indicator of the size ranges present in the different management areas. Most of the areas with relatively high percentages of (local) silver eel to (local) total eel biomass are more inland (south-east), while some of the areas with the lowest percentage are close to the coast (Figure 3). Note that the management area with the highest percentage of silver eel based on total silver eel biomass (Figure 2, 13\%) has a relatively low percentage of local silver eel based on local total eel biomass (Figure 3). This suggests that the eel stock in that area is relatively young. The area with the highest percentage of silver eel to local total eel biomass (38\%)(Figure 3) has little silver eel of the total silver eel biomass (Figure 2), indicating few but large eels. 


\section{Table IV}

Total eel and silver eel density and biomass corrected for catch efficiency of 0.2 and effective surface area per water body type for the regionally managed waters and per river section or lake for the nationally managed waters. For those regionally managed water types that were not sampled the overall average eel density of $7.1 \mathrm{~kg} / \mathrm{ha}$ and the overall average silver eel density of $1.3 \mathrm{~kg} /$ were used. For the river sections the density of the main riverbed and side channels is given; the biomass estimate is for the river section as a whole.

\begin{tabular}{|c|c|c|c|c|}
\hline \multirow[t]{2}{*}{ Water Type } & \multicolumn{2}{|l|}{ Eel } & \multicolumn{2}{|c|}{ Silver eel } \\
\hline & $\begin{array}{l}\text { Density } \\
\text { (kg/ha) }\end{array}$ & $\begin{array}{l}\text { Biomass } \\
\text { (tonnes) }\end{array}$ & $\begin{array}{l}\text { Density } \\
\text { (kg/ha) }\end{array}$ & $\begin{array}{l}\text { Biomass } \\
\text { (tonnes) }\end{array}$ \\
\hline M10 & 6.9 & 33.8 & 1.1 & 5.44 \\
\hline M14 & 10.2 & 964.19 & 1.4 & 131.9 \\
\hline M1a & 1.6 & 1.06 & 0.5 & 0.35 \\
\hline M2 & 5.3 & 0.23 & 1.2 & 0.05 \\
\hline M20 & 11.9 & 133.89 & 2.1 & 24.06 \\
\hline M23 & 0.0 & 0 & 0.0 & 0 \\
\hline M27 & 7.3 & 415.81 & 1.2 & 65.95 \\
\hline M3 & 4.8 & 49.97 & 1.1 & 11.01 \\
\hline M6a & 5.3 & 9.43 & 1.1 & 1.93 \\
\hline M6b & 11.8 & 61.32 & 1.2 & 6.12 \\
\hline M7b & 7.0 & 65.1 & 0.8 & 7.32 \\
\hline M8 & 0.9 & 2.89 & 0.4 & 1.22 \\
\hline R12 & 3.0 & 0.7 & 0.7 & 0.17 \\
\hline R14 & 0.0 & 0 & 0.0 & 0 \\
\hline R18 & 8.7 & 1.66 & 2.4 & 0.46 \\
\hline R4 & 2.0 & 0.74 & 0.5 & 0.17 \\
\hline R5 & 3.9 & 17.24 & 0.8 & 3.67 \\
\hline R6 & 7.9 & 71.6 & 1.2 & 11.11 \\
\hline R7 & 39.3 & 226.4 & 7.6 & 43.83 \\
\hline R8 & 3.9 & 0.24 & 1.2 & 0.07 \\
\hline M1b & 7.1 & 0 & 1.3 & 0 \\
\hline M30 & 7.1 & 42.09 & 1.3 & 7.85 \\
\hline M7a & 7.1 & 0.27 & 1.3 & 0.05 \\
\hline R13 & 7.1 & 0.16 & 1.3 & 0.03 \\
\hline R15 & 7.1 & 0.78 & 1.3 & 0.15 \\
\hline R17 & 7.1 & 0.26 & 1.3 & 0.05 \\
\hline Ditches $\dagger$ & 2.0 & 330 & & 49.5 \\
\hline \multirow[t]{2}{*}{ subtotal regional } & & 2430.82 & & 372.46 \\
\hline & main/channel & & main/channel & \\
\hline Benedenloop Gelderse IJssel & $0.4 / 5.4$ & 4.39 & $0.08 / 0.73$ & 0.65 \\
\hline Beneden Rivieren & $7.1 / 2.9$ & 339.93 & $0.65 / 0.47$ & 31.92 \\
\hline Gelderse Poort & $0.3 / 0.1$ & 4.18 & $0.02 / 0.02$ & 0.37 \\
\hline Getijdenlek & $3.4 / 1.0$ & 4.5 & $0.21 / 0$ & 0.26 \\
\hline Getijden Maas & $2.1 / 5.6$ & 17.45 & $0.53 / 1.31$ & 4.23 \\
\hline Grensmaas & $35.5 / 20.9$ & 121.15 & $7.60 / 4.88$ & 26.84 \\
\hline Twentekanaal & 0 & 0 & 0 & 0 \\
\hline Zandmaas & $6.6 / 21.7$ & 112.13 & $2.14 / 5.46$ & 30.81 \\
\hline Lake Volkerak-Zoommeer & 11.5 & 139.1 & 3.07 & 37.15 \\
\hline Noordzeekanaal ${ }^{\star \dagger} \dagger$ & 8.2 & 45.3 & & 6.8 \\
\hline Lake Grevelingenmeer ${ }^{*} \dagger$ & 6.1 & 37 & & 5 \\
\hline Lake IJsselmeer $\star \dagger$ & 7.8 & 384 & & 57 \\
\hline Lake Markenmeer ${ }^{\star} \dagger$ & 9.1 & 277 & & 42 \\
\hline Lake Veluwerandmeren* ${ }^{*}$ & 6.4 & 41 & & 6 \\
\hline subtotal national & & 1527.13 & & 249.03 \\
\hline TOTAL & & 3957.95 & & 619.59 \\
\hline
\end{tabular}

* Only eel $>30 \mathrm{~cm}$ was estimated as smaller sizes were not present in the landings. $\dagger$ The silver eel estimate is assumed to be $15 \%$ of the estimated yellow eel stock. 


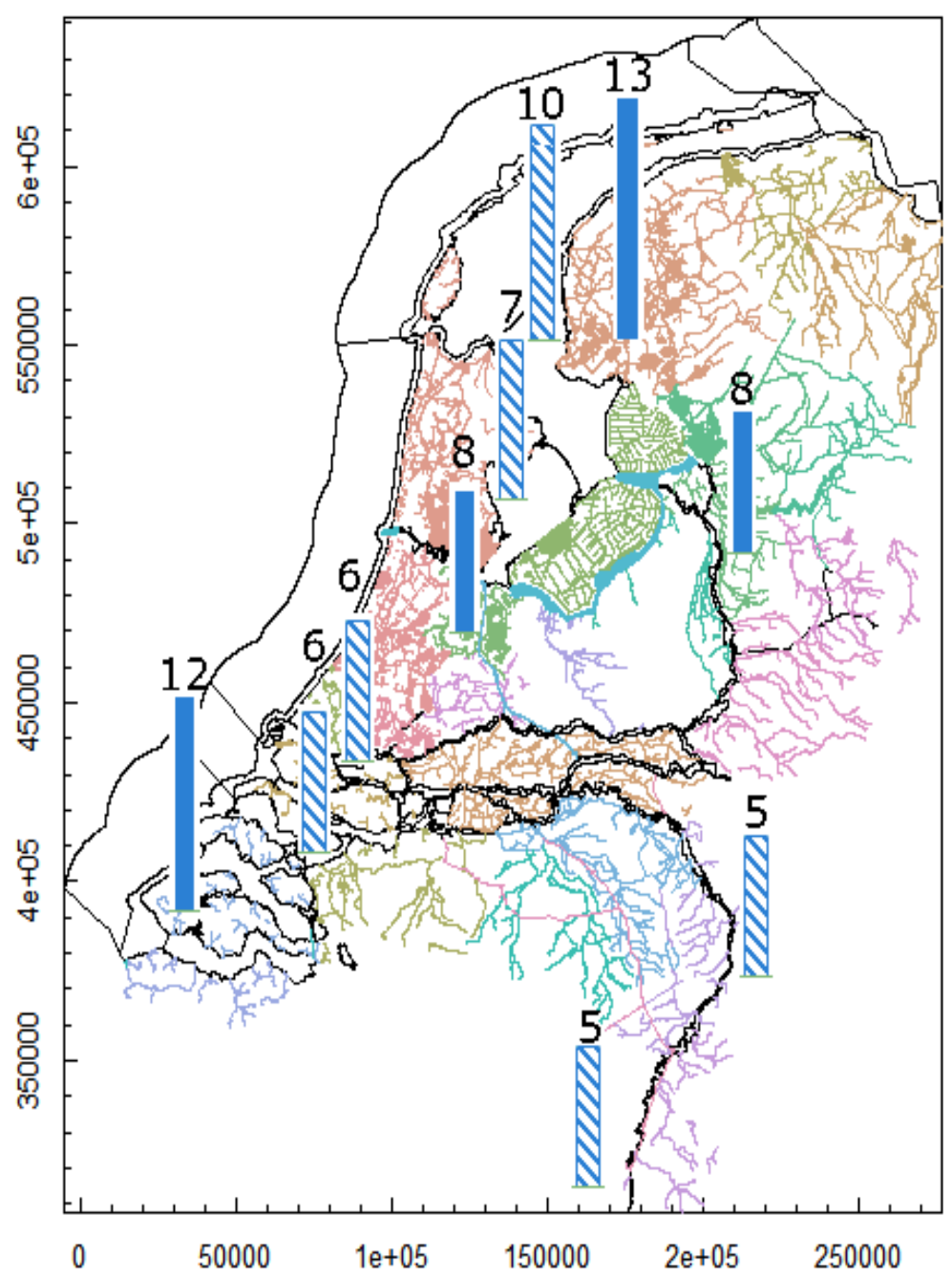

\section{Figure 2}

Local silver eel biomass contributions per water management area as a percentage (\%) of the national total silver eel biomass (estimates of eel in the ditches as presented in Table IV are excluded). For clarity reasons only percentages of 5\% and higher are shown. The different colours denote water bodies of different water management areas. Solid bars represent regionally managed waters and hatched bars represent nationally managed waters.

A similar pattern, with the highest percentages of local silver eel relative to local total eel, holds for the nationally managed waters. The highest percentages of silver eel biomass to local total eel biomass are in the east in the more upstream sections of the river Meuse (Zandmaas 27\% and Grensmaas 22\%). However, Lake Volkerak-Zoommeer and the river section Getijden Maas also have high percentages of local silver eel to local total eel biomass (Figure 4), although close to the coast. Note that the silver eel percentage of $15 \%$ in Lake Markermeer, Lake IJsselmeer, Lake Veluwerandmeren, Lake Grevelingenmeer and Noordzeekanaal (to the west) was assumed, as for these water bodies the reported landings were used to estimate the eel stock, for which no length-frequency distribution was available.

\section{DISCUSSION}

Using the WFD sampling in a static GIS approach can be used to determine the size of the eel stock in a situation where regional scale estimates are appreciated. There are limitations to this method which will be discussed below. We estimate a total of 3957 tonnes eel of 


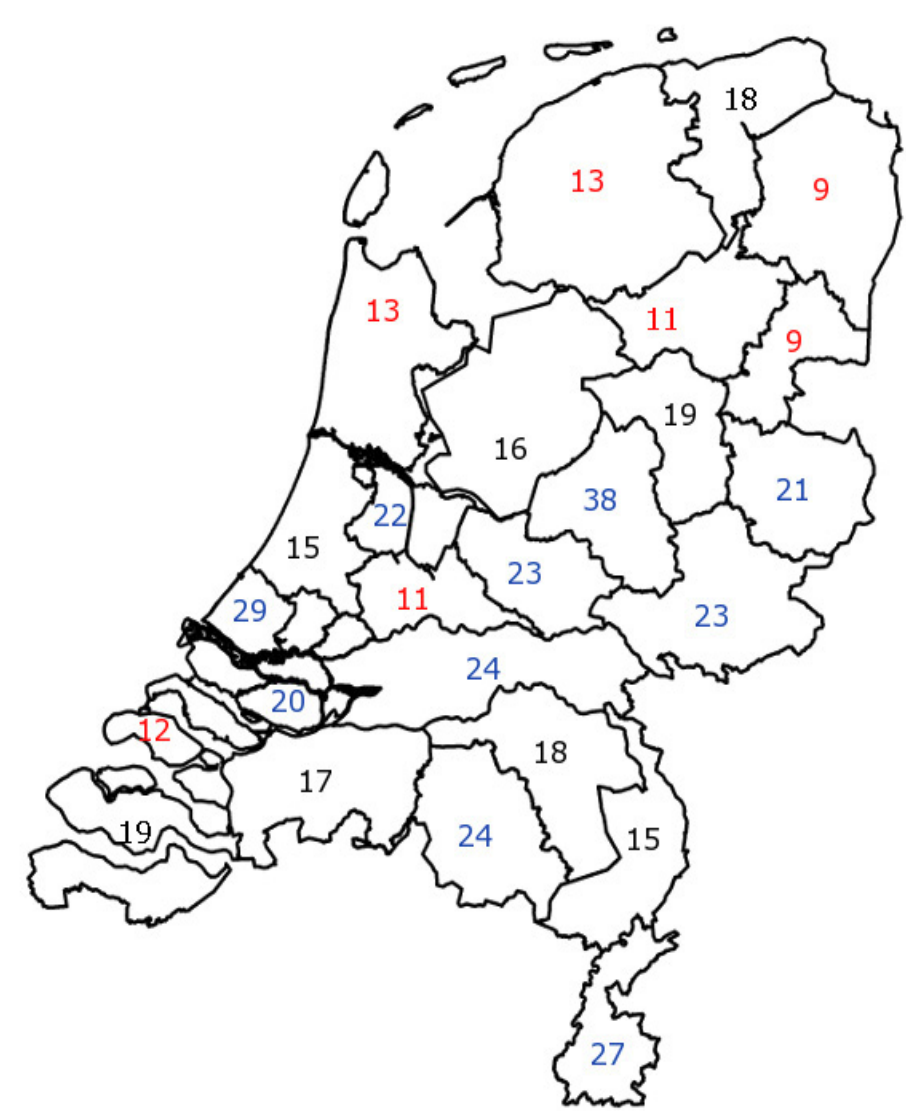

\section{Figure 3}

Local silver eel biomass as a percentage (\%) of local total eel biomass per regional water management area. Only percentages more than 20\% (blue bars) and less than $14 \%$ (red bars) are shown for clarity reasons; intermediate values were left out.

which 620 tonnes are silver eel (before migration), in the regionally and nationally managed waters combined. This is twice the silver eel biomass estimate of the Dutch management plan of 2009 (estimated at 225-315 tonnes) in which the regionally managed waters and the WFD sampling were not taken into account (Ministry of Agriculture, 2009). Of the total eel biomass, $61 \%$ is estimated to be in the regionally managed waters. The small water bodies in The Netherlands hence contain more eel than the large nationally managed water bodies. The many small water bodies make up $65 \%$ of the total freshwater surface. This shows the need for the inclusion of the regionally managed water bodies in stock assessments for eel and possibly also for other freshwater or diadromous fish species.

The regional management area approach clarifies where most eel and silver eel biomass is located. It also provides information on where measures such as a reduction in migration mortality of silver eel will enhance overall silver eel escapement most effectively. In addition, the approach shows that measures improving escapement on small regional scales might be worthwhile to increase overall escapement of silver eel. Based on the results presented here, a GIS approach could be used to identify eel hotspots and to localise, for example, the most profitable areas or barriers (manuscript in prep.) for improvement of silver eel migration (Laffaille et al., 2009).

Differences in contribution of the regionally managed waters to the total eel stock exist, among management areas and water types. Especially the estimates for lake types (M14 and M27) are high due to relatively high density $\left(\mathrm{kg} \cdot \mathrm{ha}^{-1}\right)$ levels and the large surface area of these types. Also, the added ditches, that are hardly considered within the WFD, contain $8 \%$ of the eel biomass, mostly due to the large number of ditches present in The Netherlands. 


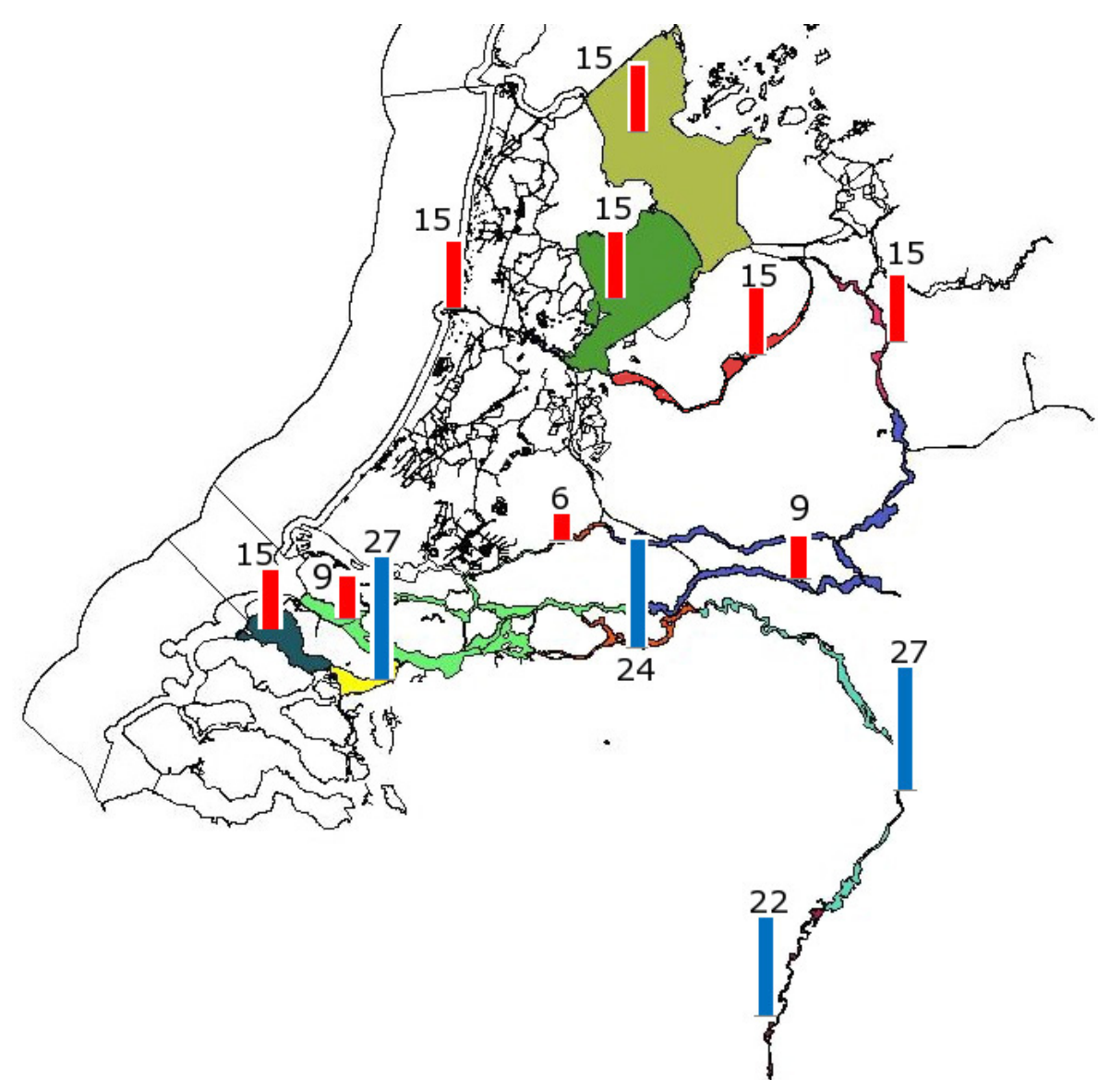

Figure 4

Silver eel biomass as a percentage (\%) of total eel biomass for the nationally managed water bodies. Blue bars represent values above the average (average is 15\%) and red bars represent values below the average. Thick black lines indicate hydro power stations. Note that the lake in the south-west (in green) with $14 \%$ silver eel is not connected to the adjacent lake to its right (in yellow) with $27 \%$ silver eel.

The difference in silver eel biomass among the coastal regions (Figure 2) cannot be explained by a difference in water surface area alone. These differences are most likely due to a combination of factors, including the timing of sampling and presence of water types with different density, but also differences in accessibility. The samples from the data used were from all seasons, including the migration season of silver eel. This prevents a proper distinction between making an estimate of resident eel or migrating eel and can obscure the results on the spatial distribution of the percentages of silver eel. Indeed, this will be the case especially for the large rivers, lakes and smaller waters on migration routes where silver eel accumulates during migration. For those regional waters where silver eel only migrate out this is less of a problem. This would lead to a similar silver eel drain in all regional areas, which does not effect a comparison among regional waters. The random selection of water bodies to sample within the WFD helps to prevent sampling certain regions in the same season each year, but a bias to the sampling period at a regional level cannot be excluded.

Differences in accessibility of the areas include the presence of a sea - freshwater connection as well as the absence of barriers. Barriers obstruct the escapement of silver eel and the influx of glass eel, although the introduction of glass eel by humans may enhance the latter. A comparison of silver eel biomass as a percentage of the total silver eel biomass (Figure 2) and silver eel biomass as a percentage of the total eel biomass (Figure 3) suggests in general a difference between the coastal regions, contributing most to silver eel biomass, and the regions to the south-eastern part with little contribution to the silver eel biomass, yet with the 
most silver eel as a percentage of the regional stock. This supports findings in other countries with a decreasing eel density as a function of distance to the coast (Lasne et al., 2008).

The migration of silver eel, or the lack thereof, will also affect silver eel percentages. Lake Volkerak-Zoommeer has a high percentage $(27 \%)$ of silver eel relative to the total eel biomass, especially compared with the adjacent Lake Grevelingenmeer. However, the two lakes are separated by a dam, preventing exchange of fish between the lakes. Lake Grevelingenmeer is connected to the North Sea through a dam (Brouwersdam). Lake Volkerak-Zoommeer is not connected to the North Sea directly. Migrating silver eel have to pass the ship locks in the Philipsdam, which have a complicated design to prevent freshwater from the lake entering the saltwater Eastern Scheld and vice versa. Alternatively, silver eel must pass the outlet sluices of Bath far more to the south before reaching the sea. Both these sluices may form an obstruction for migrating silver eel, resulting in high silver eel concentrations in a lake close to the North Sea.

Catch efficiencies of electric dipping are likely to depend on the type of water body, the substrate, the time of day, the settings of the gear, the size of the fish, and the experience of the staff operating the gear (Beaumont et al., 2002). Here we used the $20 \%$ catch efficiency assumed by The Dutch "Stichting Toegepast Onderzoek Waterbeheer", the research platform for the Dutch regional water managers (STOWA, 2003). Estimates of catch efficiencies of eel using electric dipping nets are scarce and may be specific to the type of water body, habitat and gear. Naismith and Knights (1990) assumed a catch efficiency for eel using electrofishing gear of $27 \%$ in a river, whereas Baldwin and Aprahamian (2012) estimated efficiencies of approximately $60 \%$ in small rivers. Aprahamian (1986) showed size-selective effects of electrofishing, with estimated mean probabilities of capture from 0.36 for the smallest (youngest) eels to 0.59 for the largest (oldest). Carrs et al. (1999) reported estimated capture probabilities of 0.715 and 0.751 for lochs and streams, respectively. Stevens et al. (2009a) in an evaluation of the Belgian eel management plan assumed catch efficiencies of $66 \%$. Assuming a different catch efficiency changes the total biomass estimate. If a catch efficiency of $60 \%$ were used, as was found by (Baldwin and Aprahamian) (2012), then the total eel biomass estimate would equal 2392 tonnes, instead of 3947 tonnes using the catch efficiency of $20 \%$ of the STOWA (STOWA, 2003). However, assuming a different catch efficiency does not change the percentages of biomass in regional or national waters, nor does it change the percentages of silver eel to eel, or regional differences. Note that differences in catch efficiency among water bodies and types would change the result presented here. Catch efficiency in smaller water bodies, such as ditches, might be higher than in larger rivers. This would mean that the results presented here overestimate eel in small water bodies, when assuming equal scaling with surface area and perimeter. Although an estimation of catch efficiency for all water types present in the Netherlands is not feasible, there is at present a study being conducted to assess the catch efficiency in ditches. Catchability of differently-sized fish also plays a role, with smaller fish having a reduced catchability (Bevacqua et al. 2007). If a correction factor was known for the gear used in the Netherlands a rescaling would result in an equal downscaling of the fraction of silver eel across regions.

Using the regionally managed WFD monitoring data proved a valuable addition to the nationally managed WFD monitoring data. The regional monitoring for the WFD was set up to assess the ecological status of water bodies and not to provide data for stock assessments. However, although the monitoring method is not designed specifically to catch eel it is an adequate method to look at the spatial distribution and provide an estimate of eel biomass. Most importantly, the sampling follows a standardised protocol, ensuring continuity in methods and allowing one to merge data from different regions and years. However, uncertainties of catchability and efficiency for eel exist, which will need to be addressed. Another disadvantage is that not all water bodies in The Netherlands are classified as WFD water bodies, although the majority (100\% of large lakes and rivers, $90 \%$ of canals and larger waterways, and $70 \%$ of smaller streaming waters) (PBL, 2010) is accounted for. Here we attempted to correct for the ditches that are not considered to be WFD water bodies as they form a large part (only $0.5 \%$ considered, of a total length of $330000 \mathrm{~km}$ ) of the water surface in the Netherlands. 
This correction could unfortunately only be used at a national level as a quantification of the spatial distribution of ditches is not known. However, since most ditches are located in the regions in the western part of the country it can be assumed that the eel biomass in those regions might be underestimated. On a national level this does not play a role as the estimate of eel biomass in ditches is considered.

In conclusion, we estimated that more than half of the eel stock in The Netherlands is in the many small waters, which historically were not part of the stock assessment. Not taking these smaller, regionally managed water bodies into account resulted in a strong underestimation of the stock size. The regional approach allows for a better identification of where measures aiming at stock recovery would be most beneficial in terms of aiding silver eel migration. This makes the WFD fishery independent monitoring data a useful source of fish sampling data from which stocks and their assessments could profit in complex delta areas.

\section{ACKNOWLEDGEMENTS}

This research was funded by the Dutch Government, Ministry of Economic Affairs. The authors are grateful for the comments of the editor and reviewers which improved the manuscript.

\section{REFERENCES}

Aprahamian M.W., 1986. Eel (Anguilla anguilla L.) production in the River Severn. England. Pol. Arch. Hydrobiol., 33, 373-389.

Aprahamian M.W., Walker A.M., Williams B., Bark A. and Knights B., 2007. On the application of models of European eel (Anguilla anguilla) production and escapement to the development of Eel Management plans: the River Severn. ICES J. Mar. Sci., 64, 1472-1482.

Baldwin L. and Aprahamian M., 2012. An evaluation of electric fishing for assessment of resident eel in rivers. Fisheries Research 123, 4-8.

Bevacqua D., Melià P., Crivelli A.J., Gatto M. and De Leo G.A., 2007. Multi-objective assessment of conservation measures for the European eel (Anguilla anguilla): an application to the Camargue lagoons. ICES J. Mar. Sci., 64, 1483-1490.

Bierman S.M., N. Tien N., van de Wolfshaar K.E., Winter H.V. and de Graaf M., 2012. Evaluation of the Dutch Eel Management Plan 2009-2011. IMARES Report C067/12.

Carrs D.N., Elston D.A., Nelson K.C. and Kruuk H., 1999. Spatial and temporal trends in unexploited yellow eel stocks in two shallow lakes and associated streams. J. Fish. Biol., 55, 636-654.

Ciccotti E., Leone C., Bevacqua D., De Leo G., Tancioni L. and Capoccioni F., 2012. Integrating habitat restoration and fisheries management: A small-scale case-study to support EEL conservation at the global scale. Knowl. Managt. Aquatic Ecosyst. 4007.

De Graaf M., Bierman S.M. and Van de Wolfshaar K.E., 2011. Schieraal uittrek gesloten gebieden. IMARES Report C121/11.

Dekker W., 2000. A Procrustean assessment of the European eel stock. ICES J. Mar. Sci., 57, 938-947.

Jellyman D.J. and Chisnall B.L., 1999. Habitat preferences of shorfinned eels (Anguilla australis) in two New Zealand lowland lakes. N. Z. J. Mar. Freshw. Res., 33, 233-248.

Laffaille P., Lasne E. and Baisez A., 2009. Effects of improving longitudinal connectivity on colonisation and distribution of European eel in the Loire catchment, France. Ecol. Freshw. Fish., 18, 610-619.

Lasne E., Acou A., Vila-Gispert A. and Laffaille P., 2008. European eel distribution and body condition in a river floodplain: effect of longitudinal and lateral connectivity. Ecol. Freshw. Fish., 17, 567-576.

Ministry of Agriculture, n.a.f.q., 2009. The Netherlands Eel Management Plan.

Naismith I.A. and Knights B., 1990. Studies of sampling methods and of techniques for estimating populations of eels, Anguilla anguilla L. Aquaculture and Fisheries Management 21, 357-367.

Noble R.A.A., Cowx I.G., Goffaux D. and Kestemont P., 2007. Assessing the health of European rivers using functional ecological guilds of fish communities: Standardising species classification and approaches to metric selection. Fish. Manag. Ecol., 14, 381-392. 
Oeberst R. and Fladung E., 2012. German Eel Model (GEM II) for describing eel, Anguilla anguilla (L.), stock dynamics in the river Elbe system. Inf. Fish. Res., 59, 9-17.

PBL, 2010. Basiskaart aquatisch: de watertypenkaart. In: leefomgeving, P.v.d. (ed.).

R Development Core Team, 2005. R: A Language and Environment for Statistical Computing. R Foundation for Statistical Computing, Vienna, Austria.

Schulze T., Kahl U., Radke R.J. and Benndorf J., 2004. Consumption, abundance and habitat use of Anguilla anguilla in a mesotrophic reservoir. J. Fish. Biol., 65, 1543-1562.

Stevens M., Coeck J. and van Vessem J., 2009a. Wetenschappelijke onderbouwing van de palingbeheerplannen voor Vlaanderen. Instituut voor Natuur- en Bosonderzoek, Brussel.

Stevens M., Coeck J. and van Vessem J., 2009b. Wetenschappelijke onderbouwing van de palingbeheerplannen voor Vlaanderen. Rapporten van het Instituut voor Natuur- en Bosonderzoek 2009 (INBO.R.2009.40). Instituut voor Natuur- en Bosonderzoek, Brussel.

STOWA, 2003. Handboek Visstandbemonstering.

STOWA, 2007a. Omschrijving MEP en maatlatten voor sloten en kanalen voor de Kaderrichtlijn Water. In: STOWA (ed.).

STOWA, 2007b. Referenties en maatlatten voor natuurlijke watertypen voor de kaderrichtlijn water. In: STOWA (ed.).

Van Keeken O., Bierman S.M., Wiegerinck J.A.M. and Goudswaard P.C., 2010. Proefproject marktbemonstering aal 2009 IMARES Report C028/10.

Van Keeken O., Bierman S.M., Wiegerinck H., Goudswaard K. and Kuijs E., 2011. Proefproject marktbemonstering aal Voortgang 2010. IMARES Report C053/11.

Van Kessel N., Spikmans F., Hoogerwerf G. and Kranenbarg J., 2010. Jaarrapportage actieve monitoring zoete rijkswateren. Samenstelling van de visstand in de grote rivieren gedurende het winterhalfjaar 2009-2010. Natuurbalans-Limens Divergens BV \& Stichting RAVON, Nijmegen. 